\title{
Evaluation of Industrial Work Practice Program Competence of Motorcycle Engineering Expertise Based on CIPP Model
}

\author{
M. Sidik ${ }^{1}$, Billy Tunas ${ }^{2}$, M. Entang ${ }^{3}$ \\ ${ }^{1,2,3}$ Post Graduate Program, Universitas Pakuan Bogor, Indonesia
}

*Corresponding Author: M. Sidik, Post Graduate Program, Universitas Pakuan Bogor, Indonesia.

\begin{abstract}
The research is aimed to describe the effectiveness of the implementation of the industrial work practice in vocational high schools in Muaro Jambi Regency. The study applies a descriptive qualitative approach with the concept of comprehensive program evaluation covering context, input, process, and product (CIPP). Context includes goals, targets, and policies of the industrial work practice. The input comprises program plans, action methods, organization structure, mechanism procedure, monitoring and controlling, human resource support, facility support and budget support of the industrial work practice. The process covers acts of location survey, cooperation agreement, student briefing, student placement, student delivery and handover, student counseling, and observation, control, and evaluation of the industrial work practice program. Product covers achievements, advantages, and effects of the industrial work practice program. Data is collected by observation, the study of documentation, interview, and Focus Group Discussion. Based on the descriptive analysis, the result of the research shows that the component of context gains an effect with a satisfactory category. The part of input increases an effect with a good class, and the component of process achieves a result with a good group. Finally, the part of product gains an effect with a good level. All criteria of the evaluation, therefore, are fulfilled, and the industrial work practice program can still be continued with some notes for the improvement of the quality of activities in all components.
\end{abstract}

Keywords: program evaluation, the industrial work practice, CIPP model

\section{INTRODUCTION}

A competent and skilled workforce one of whom was born of a qualified vocational education and training that is relevant to the demands of the business/industry. Every graduate student of vocational high school or sekolah menengah kejuruan (smk) is required to have a skill and ready to work. But in reality, smk graduates have not been fully recognized by the business world/industry (companies) and individual agencies. Therefore, the government seeks to establish a multiple system education program by implementing industrial work practices so that every smk graduate has an experience in the business world or workplace before entering the business/industry real after graduated from the school.

Industrial work practice is a form of business exploitation program that is obtained through direct work activities in the workplace to achieve a level of professional expertise. Professional expertise can only be established through the three top elements of science, techniques, and tips. Science and techniques can be learned when and where they are, a set of tips cannot be taught but can be mastered through the process of working directly with the profession itself. Industrial work practices develop students' competencies in industrial engineering that include elements of knowledge, attitude, and skills in industrial design. Narrowly industrial work practices foster industrial design skills through direct activities in an industrial environment. During the industry, students can develop the experience of relationships between people that is how to socialize and socialize in the industrial environment.

The primary focus of this research is the evaluation of industrial work practice program of competence of motorcycle engineering skill at public vocational high schools in Muaro Jambi Regency, Indonesia. The sub focus of research includes the following:

1) The underlying needs of the program include the objectives, targets, and policies of industrial work practice programs of competence in motorcycle engineering expertise.

2) Preparation of technical internship program of competency of vehicle engineering expertise includes program activities, procedures, and mechanisms, organizational structure, monitoring 
and control, human resources support, facilities and infrastructure and budget required by industrial work practice program competence of motorcycle engineering expertise.

3) Implementation of technical internship program of motorcycle engineering expertise related to the implementation of industrial training location survey, implementation of cooperation agreement (MOU), implementation of student briefing, implementation of student placement, implementation of student submission, implementation of student guidance, supervision and control implementation, industrial work practice competence of motorcycle engineering expertise.

4) The results and benefits and impact of the implementation of industrial work practice of vehicle design skills ability to meet expectations.

\section{LITERATURE REVIEW}

Program evaluation is defined as "the application of assessment approaches, techniques, and knowledge to systematically assess and improve the planning, implementation, and effectiveness of the program." A program must demonstrate two functions for success and sustainability: 1) internally, the program must ensure the smooth transformation of inputs into the output as desired, 2) externally, a program is required to continue to interact with its environment to obtain resources and support which is needed for program sustainability. It is also suggested that each program evaluation can be conceptualized to have five components namely input, transformation, output, feedback, and environment. (Huey Tsyh Chen, 2005). Others argue that program evaluation is oriented around the attention of the policy makers of the funders characteristically incorporates the underlying cause questions about the extent to which the program has achieved its desired objectives ( Norman $\mathrm{K}$ Denzin and Yvonna S Lincoln, 2000). Furthermore, it is said that program evaluation is a combination and variation of the theory and practice used broadly in public, non-profit and in the private sector organizations to produce information for planning, design, and implementation. Program evaluation is also an assessment of the outcomes of efforts to address and resolve the issues used in policies and programs (James C. Mc David, Laura R.L. Hawthorn, 2005). It further defines that: "program evaluation is the application of judgment, Program evaluation is the use of systematic methods to address the question of monitoring and implementation of a program or program of impact. (Langbein, Laura \&Claire L. Felbinger, 2006) Sharon explains that program evaluation is an investigation or data collection activity that generates information about the value of a program in which the information is useful for those who want to make decisions. Program evaluation involves three main concepts: a) systematic investigation, b) assessment of benefits, values or interests, c) information for decision making (Sharon F. Rallis \& Kathleen A. Bolland, 2005). Program evaluation is used for some purposes: maintaining quality, identifying challenge areas, facilitating program improvement and provides data for reports to State agencies, accrediting agencies and government councils (David et al. 2005).

Model evaluation of the traditional program and widely used as a strategy or work guidelines in the implementation of program evaluation is; (a) evaluation of the Kirkpatrick Model, (b) evaluation of the CIPP Model, (c) Evaluation of the Provus Model, (d) Evaluation of the Stake Model, (e) evaluation of the Brinkerhoff Model. In this research use CIPP model evaluation.

Industrial work practices are also interpreted as a pattern of training and training organized jointly between SMK and industry or professional associations as a partner institution. The stages are ranging from the planning stage, implementation to evaluation and certification which is a unified program by using various alternative forms of application day release, block release and so on (Dikmenjur, 2008). In the school, the learners learn with the teachers while in the business world / industrial world the students practice with the existing instructors in the corporate world and industry.

Implementation of CIPP model program evaluation on industrial engineering practice program of competency of motorcycle engineering skill at SMKN in Muaro Jambi Regency can be described in the following table: 
Evaluation of Industrial Work Practice Program Competence of Motorcycle Engineering Expertise Based on CIPP Model

Table1. Application of Program Evaluation of CIPP Model in Industrial Work Practice Program Competence of Motorcycle Engineering Expertise

\begin{tabular}{|c|c|c|c|}
\hline Context & Input & Process & Product \\
\hline $\begin{array}{l}\text { Assessing the objectives } \\
\text { of industrial work } \\
\text { practices programs } \\
\text { capability of vehicle } \\
\text { engineering expertise } \\
\text { oriented to needs } \\
\text { analysis, objective } \\
\text { formulation require } \\
\text { ments, targets and } \\
\text { policies of industrial } \\
\text { training programs }\end{array}$ & $\begin{array}{l}\text { Assessing readiness in } \\
\text { implementing industrial } \\
\text { work practice program } \\
\text { competence of motorcycle } \\
\text { engineering expertise } \\
\text { includes activity plan, way } \\
\text { of acting, mechanism } \\
\text { procedure, organizational } \\
\text { structure of monitoring and } \\
\text { controlling, human } \\
\text { resources support, infra } \\
\text { structure support and } \\
\text { budget support }\end{array}$ & $\begin{array}{l}\text { Assessing the effectiveness } \\
\text { and efficiency of the } \\
\text { implementation of industrial } \\
\text { engineering practice } \\
\text { programs of competence of } \\
\text { motorcycle engineering } \\
\text { expertise by looking at site } \\
\text { survey implementation, } \\
\text { cooperation agreement, } \\
\text { student briefing, student } \\
\text { placement, delivery and } \\
\text { student submission, student } \\
\text { guidance, supervision and } \\
\text { control }\end{array}$ & $\begin{array}{l}\text { Assessing the } \\
\text { results of the } \\
\text { achievement of } \\
\text { technical internship } \\
\text { program of } \\
\text { competency of } \\
\text { motorcycle } \\
\text { engineering skill in } \\
\text { the form of } \\
\text { performance, } \\
\text { benefits, and impact } \\
\text { of industrial work } \\
\text { practices program } \\
\text { competence of } \\
\text { motorcycle } \\
\text { engineering skill }\end{array}$ \\
\hline
\end{tabular}

\section{Methodology}

This study aims to obtain empirical and analytical data on substantive and significant issues that affect the implementation of industrial engineering practice programs capability of motorcycle engineering expertise. The evaluation model used in this research is the formative and summative evaluation model developed by Stufflebeam known as CIPP evaluation model. The formative evaluation includes evaluation of context, input and process components and the summative evaluation includes product components. This CIPP evaluation model provides a sharp and comprehensive review of the underlying components consisting of (a) the context component includes policy, objective formulation, targets of technical internship program of competence of motorcycle engineering skill, (b) input element includes activity plan programs, procedures and mechanisms, monitoring and control, resource support covering human resources, facilities and infrastructure and budget required for industrial engineering competency work program competency, (c) process components including the implementation of site surveys, cooperation agreements, (d) product components including achievements and benefits as well as impact of the implementation of industrial work practices program competence of motorcycle engineering expertise for students, schools, the world business and society. Based on the sources and types of data collected, the data collection techniques in this evaluative research is by the process of documentation of written data, interviews, observations and focus group discussions (FGD). Rating scale $1-5, \mathrm{E}=$ very poor $(0.1-1.0), \mathrm{D}=$ poor $(1,1-2,0), \mathrm{C}=$ good enough $(2,1-3,0), \mathrm{B}=\operatorname{good}(3.1-4.0), \mathrm{A}=$ very good (4.1-5.0).

\section{RESULT AND DISCUSSION}

Recapitulation of research results on content components including aspects formulation of program objectives, formulation of program target and formulation of program policies are shown in the following table.

Table2. Recapitulation of Program Objectives Formulation

\begin{tabular}{|c|c|c|c|c|c|c|c|}
\hline \multirow{3}{*}{ Aspects } & \multicolumn{5}{|c|}{ Assessment categories } & \multirow{3}{*}{ Score } & \multirow{3}{*}{ Grades } \\
\hline & \multirow[t]{2}{*}{ Observation } & \multirow[t]{2}{*}{ Documentation Study } & \multicolumn{3}{|c|}{ Interview } & & \\
\hline & & & Info 1 & Info 2 & Info 3 & & \\
\hline $\begin{array}{c}\text { Program } \\
\text { Objectives } \\
\text { Formulation }\end{array}$ & - & 3.0 & 2.2 & 2.6 & 2.3 & 2.6 & $\mathrm{C}$ \\
\hline
\end{tabular}

Table3. Recapitulation of Program Target Formulation

\begin{tabular}{|c|c|c|c|c|c|c|c|}
\hline \multirow{2}{*}{ Aspects } & \multicolumn{4}{|c|}{ Assessment categories } & \multirow{2}{*}{ Score } & \multirow{2}{*}{ Grades } \\
\cline { 2 - 5 } & Observation & Documentation Study & \multicolumn{3}{|c|}{ Interview } & \\
\cline { 3 - 6 } & & & Info 1 & Info 2 & Info 3 & & \\
\hline $\begin{array}{c}\text { Program } \\
\text { Target } \\
\text { Formulation }\end{array}$ & - & 3,0 & 3,0 & 3,0 & 2,9 & 3,0 & C \\
\hline
\end{tabular}


Evaluation of Industrial Work Practice Program Competence of Motorcycle Engineering Expertise Based on CIPP Model

Table4. Recapitulation of Program Policy Formulation

\begin{tabular}{|c|c|c|c|c|c|c|c|}
\hline \multirow{2}{*}{ Aspects } & \multicolumn{3}{|c|}{ Assessment categories } & \multirow{2}{*}{ Score } & \multirow{2}{*}{ Grades } \\
\cline { 2 - 5 } & Observation & Documentation Study & \multicolumn{3}{|c|}{ Interview } & \\
\cline { 3 - 6 } & & & Info 1 & Info 2 & Info 3 & & \\
\hline $\begin{array}{c}\text { Program } \\
\text { Policy Policy } \\
\text { Formulation }\end{array}$ & - & 3,0 & 2,5 & 3,0 & 3,0 & 2,9 & $\mathrm{C}$ \\
\hline
\end{tabular}

Based on the evaluation results on aspects of the context component, the average grade of 2.83 with the predicate $\mathrm{C}$ was generated and resulted in the decision that the program can be continued with the improvement.

Recapitulation of research result of input component covering readiness aspect of program activity, readiness of program activity action, preparedness of program operation mechanism, readiness of organizational structure of program activity, readiness of monitoring and control of program activity, preparation of human resources support program activity, , and the availability of budget support for program activities are presented in the following table.

Table5. Recapitulation of program activity readiness

\begin{tabular}{|c|c|c|c|c|c|c|c|}
\hline \multirow{2}{*}{ Aspects } & \multicolumn{3}{|c|}{ Assessment categories } & \multirow{2}{*}{ Score } & \multirow{2}{*}{ Grades } \\
\cline { 2 - 5 } & Observation & Documentation Study & \multicolumn{2}{|c|}{ Interview } & \\
\cline { 4 - 6 } & & & Info 1 & Info 2 & Info 3 & & \\
\hline $\begin{array}{c}\text { Program } \\
\text { activity } \\
\text { readiness }\end{array}$ & - & 3.3 & 2.2 & 2.8 & 3.5 & 3.0 & $\mathrm{C}$ \\
\hline
\end{tabular}

Table6. Recapitulation of readiness to act program activity

\begin{tabular}{|c|c|c|c|c|c|c|c|}
\hline \multirow{3}{*}{ Aspects } & \multicolumn{5}{|c|}{ Assessment categories } & \multirow{3}{*}{ Score } & \multirow{3}{*}{ Grades } \\
\hline & \multirow[t]{2}{*}{ Observation } & \multirow[t]{2}{*}{ Documentation Study } & \multicolumn{3}{|c|}{ Interview } & & \\
\hline & & & Info 1 & Info 2 & Info 3 & & \\
\hline $\begin{array}{c}\text { Program } \\
\text { activity } \\
\text { readiness to act }\end{array}$ & - & 3,5 & 3,3 & 3,3 & 2,7 & 3,2 & $\mathrm{~B}$ \\
\hline
\end{tabular}

Table7. Recapitulation of program mechanism readiness of program activity

\begin{tabular}{|c|c|c|c|c|c|c|c|}
\hline \multirow{3}{*}{ Aspects } & \multicolumn{5}{|c|}{ Assessment categories } & \multirow{3}{*}{ Score } & \multirow{3}{*}{ Grades } \\
\hline & \multirow[t]{2}{*}{ Observation } & \multirow{2}{*}{$\begin{array}{c}\text { Documentation } \\
\text { Study }\end{array}$} & \multicolumn{3}{|c|}{ Interview } & & \\
\hline & & & Info1 & Info2 & Info3 & & \\
\hline $\begin{array}{c}\text { Program } \\
\text { mechanism } \\
\text { readiness of } \\
\text { program activity }\end{array}$ & - & 3.5 & 2.4 & 2.6 & 3.8 & 3.1 & B \\
\hline
\end{tabular}

Table8. Recapitulation of readiness of organization structure of program activities

\begin{tabular}{|c|c|c|c|c|c|c|c|}
\hline \multirow{2}{*}{ Aspects } & \multicolumn{4}{|c|}{ Assessment categories } & \multirow{2}{*}{ Score } & \multirow{2}{*}{ Grades } \\
\cline { 2 - 6 } & Observation & $\begin{array}{c}\text { Documentation } \\
\text { Study }\end{array}$ & Info1 & Info2 & Info3 & & \\
\hline $\begin{array}{c}\text { Readiness of } \\
\text { organization } \\
\text { structure of } \\
\text { program activities }\end{array}$ & - & 4,0 & 3,3 & 3,3 & 3,8 & 3,6 & B \\
\hline
\end{tabular}

Table9. Recapitulation of monitoring preparedness and control of program activity

\begin{tabular}{|c|c|c|c|c|c|c|c|}
\hline \multirow{3}{*}{ Aspects } & \multicolumn{5}{|c|}{ Assessment categories } & \multirow{3}{*}{ Score } & \multirow{3}{*}{ Grades } \\
\hline & \multirow[t]{2}{*}{ Observation } & \multirow{2}{*}{$\begin{array}{c}\text { Documentation } \\
\text { Study }\end{array}$} & \multicolumn{3}{|c|}{ Interview } & & \\
\hline & & & Info1 & Info2 & Info3 & & \\
\hline $\begin{array}{c}\text { Monitoring and } \\
\text { control of program } \\
\text { activity }\end{array}$ & - & 3,0 & 3,3 & 3,3 & 3,0 & 3,2 & B \\
\hline
\end{tabular}


Evaluation of Industrial Work Practice Program Competence of Motorcycle Engineering Expertise Based on CIPP Model

Table10. Recapitulation of Human Resources support readiness

\begin{tabular}{|c|c|c|c|c|c|c|c|}
\hline \multirow{3}{*}{ Aspects } & \multicolumn{5}{|c|}{ Assessment categories } & \multirow{3}{*}{ Score } & \multirow{3}{*}{ Grades } \\
\hline & \multirow[t]{2}{*}{ Observation } & \multirow{2}{*}{$\begin{array}{c}\text { Documentation } \\
\text { Study }\end{array}$} & \multicolumn{3}{|c|}{ Interview } & & \\
\hline & & & Info 1 & Info 2 & Info 3 & & \\
\hline $\begin{array}{l}\text { Human } \\
\text { Resources } \\
\text { support } \\
\text { readiness }\end{array}$ & - & 3,5 & 2,5 & 2,5 & 2,5 & 2,8 & $\mathrm{C}$ \\
\hline
\end{tabular}

Table11. Recapitulation of infrastructure support readiness

\begin{tabular}{|c|c|c|c|c|c|c|c|}
\hline \multirow{2}{*}{ Aspects } & \multicolumn{3}{|c|}{ Assessment categories } & \multirow{2}{*}{ Score } & \multirow{2}{*}{ Grades } \\
\cline { 2 - 5 } & Observation & \multicolumn{2}{|c|}{$\begin{array}{c}\text { Documentation } \\
\text { Study }\end{array}$} & Info 1 & Info 2 & Info 3 & \\
\hline $\begin{array}{c}\text { Infrastructure } \\
\text { support } \\
\text { readiness }\end{array}$ & - & 3,0 & 2,7 & 2,7 & 2,7 & 2,8 & $\mathrm{C}$ \\
\hline
\end{tabular}

Table12. Recapitulation of budget support readiness

\begin{tabular}{|c|c|c|c|c|c|c|c|}
\hline \multirow{3}{*}{ Aspects } & \multicolumn{5}{|c|}{ Assessment categories } & \multirow{3}{*}{ Score } & \multirow{3}{*}{ Grades } \\
\hline & \multirow[t]{2}{*}{ Observation } & \multirow{2}{*}{$\begin{array}{c}\text { Documentation } \\
\text { Study }\end{array}$} & \multicolumn{3}{|c|}{ Interview } & & \\
\hline & & & Info 1 & Info 2 & Info 3 & & \\
\hline $\begin{array}{c}\text { Budget support } \\
\text { readiness }\end{array}$ & - & 3,5 & 3,3 & 3,3 & 3,3 & 3,4 & $\mathrm{~B}$ \\
\hline
\end{tabular}

Based on the evaluation results on the input component aspects, the average value of 3.14 with the predicate $\mathrm{B}$ was generated and led to the decision that the program can be continued with the developments.

The result of process component analysis including the implementation of location survey, cooperation agreement, student briefing, student placement, delivery and student submission, student guidance process, supervision and control, and evaluation of program activity are shown in the following tables.

Table13. Implementation of site survey

\begin{tabular}{|c|c|c|c|c|c|c|c|}
\hline \multirow{3}{*}{ Aspects } & \multicolumn{4}{|c|}{ Assessment categories } & \multirow{3}{*}{ Score } & \multirow{3}{*}{ Grades } \\
\cline { 2 - 6 } & Observation & Documentation Study & \multicolumn{3}{|c|}{ Interview } \\
\cline { 4 - 7 } & & & Info 1 & Info 2 & Info 3 & & \\
\hline Site survey & 4.0 & 3.5 & 3.3 & 3.5 & 3.3 & 3.5 & B \\
\hline
\end{tabular}

Table14. Implementation of cooperation agreements

\begin{tabular}{|c|c|c|c|c|c|c|c|}
\hline \multirow{2}{*}{ Aspects } & \multicolumn{4}{|c|}{ Assessment categories } & \multirow{3}{*}{ Score } & \multirow{2}{*}{ Grades } \\
\cline { 2 - 6 } & Observation & $\begin{array}{c}\text { Documentation } \\
\text { Study }\end{array}$ & \multicolumn{3}{|c|}{ Interview } & & \\
\cline { 3 - 6 } & & & Info 1 & Info 2 & Info 3 & & \\
\hline Cooperation agreements & 3.0 & 3.5 & 3.3 & 3.3 & 3.3 & 3.3 & B \\
\hline
\end{tabular}

Table15. Implementation of student activity orientation

\begin{tabular}{|c|c|c|c|c|c|c|c|}
\hline \multirow{2}{*}{ Aspects } & \multicolumn{3}{|c|}{ Assessment categories } & \multirow{2}{*}{ Score } & \multirow{2}{*}{ Grades } \\
\cline { 2 - 5 } & Observation & Documentation Study & \multicolumn{3}{|c|}{ Interview } & \\
\cline { 4 - 6 } & & & Info 1 & Info 2 & Info 3 & & \\
\hline $\begin{array}{c}\text { Student activity } \\
\text { orientations }\end{array}$ & 3.0 & 3.5 & 3.3 & 3.3 & 3.8 & 3.4 & $\mathrm{~B}$ \\
\hline
\end{tabular}

Table16. Implementation of student placement

\begin{tabular}{|c|c|c|c|c|c|c|c|}
\hline \multirow{2}{*}{ Aspects } & \multicolumn{4}{|c|}{ Assessment categories } & \multirow{3}{*}{ Score } & \multirow{3}{*}{ Grades } \\
\cline { 2 - 6 } & Observation & Documentation & \multicolumn{3}{|c|}{ Interview } \\
\cline { 4 - 6 } & & Study & Info 1 & Info 2 & Info 3 & & \\
\hline Student placement & 4.0 & 3.5 & 3.0 & 3.0 & 3.0 & 3.3 & B \\
\hline
\end{tabular}


Evaluation of Industrial Work Practice Program Competence of Motorcycle Engineering Expertise Based on CIPP Model

Table17. Implementation of delivery and handing students

\begin{tabular}{|c|c|c|c|c|c|c|c|}
\hline \multirow{2}{*}{ Aspects } & \multicolumn{5}{|c|}{ Assessment categories } & \multirow{3}{*}{ Score } & \multirow{2}{*}{ Grades } \\
\cline { 2 - 6 } & Observation & Documentation & \multicolumn{3}{|c|}{ Interview } & & \\
\cline { 4 - 6 } & & Study & Info 1 & Info 2 & Info 3 & & \\
Delivery and & 3.0 & 4.0 & 2.5 & 2.5 & 3.5 & 3.1 & B \\
\hline
\end{tabular}

Table18. Implementation of the student guidance process

\begin{tabular}{|c|c|c|c|c|c|c|c|}
\hline \multirow[t]{3}{*}{ Aspects } & \multicolumn{5}{|c|}{ Assessment categories } & \multirow{3}{*}{ Score } & \multirow{3}{*}{ Grades } \\
\hline & \multirow[t]{2}{*}{ Observation } & \multirow{2}{*}{$\begin{array}{c}\text { Documentation } \\
\text { Study }\end{array}$} & \multicolumn{3}{|c|}{ Interview } & & \\
\hline & & & Info 1 & Info 2 & Info 3 & & \\
\hline $\begin{array}{l}\text { Student } \\
\text { guidance } \\
\text { process }\end{array}$ & 3.0 & 4.0 & 2.8 & 3.3 & 3.3 & 3.3 & $\mathrm{~B}$ \\
\hline
\end{tabular}

Table19. Implementation of supervision and control

\begin{tabular}{|c|c|c|c|c|c|c|c|}
\hline \multirow{2}{*}{ Aspects } & \multicolumn{5}{|c|}{ Assessment categories } & \multirow{2}{*}{ Score } & \multirow{2}{*}{ Grades } \\
\cline { 2 - 6 } & Observation & Documentation & \multicolumn{3}{|c|}{ Interview } \\
\cline { 4 - 7 } & & Study & Info 1 & Info 2 & Info 3 & & \\
\hline $\begin{array}{c}\text { Supervision and } \\
\text { control }\end{array}$ & 3.0 & 4.0 & 2.8 & 2.8 & 2.8 & 3.1 & $\mathrm{~B}$ \\
\hline
\end{tabular}

Table20. Implementation of program evaluation activities

\begin{tabular}{|c|c|c|c|c|c|c|c|}
\hline \multirow[t]{3}{*}{ Aspects } & \multicolumn{5}{|c|}{ Assessment categories } & \multirow{3}{*}{ Score } & \multirow{3}{*}{ Grades } \\
\hline & \multirow[t]{2}{*}{ Observation } & \multirow{2}{*}{$\begin{array}{c}\text { Documentation } \\
\text { Study }\end{array}$} & \multicolumn{3}{|c|}{ Interview } & & \\
\hline & & & Info 1 & Info 2 & Info 3 & & \\
\hline $\begin{array}{c}\text { Program } \\
\text { evaluation } \\
\text { activities }\end{array}$ & 4.0 & 4.0 & 3.0 & 3.0 & 2.8 & 3.4 & B \\
\hline
\end{tabular}

Based on the evaluation results on aspects of the process components get an average value of 3.3 with the predicate $\mathrm{B}$ and resulted in the decision that the program can be continued with the development.

In the product component which includes program implementation outcome, program implementation benefit, and impact of program activity implementation are presented in the following tables.

Table21. Outcomes of program activity implementation

\begin{tabular}{|c|c|c|c|c|c|c|c|}
\hline \multirow{2}{*}{ Aspects } & \multicolumn{5}{|c|}{ Assessment categories } & \multirow{2}{*}{ Score } & \multirow{2}{*}{ Grades } \\
\cline { 2 - 7 } & Observation & Documentation & \multicolumn{3}{|c|}{ Interview } \\
\cline { 3 - 7 } & & Study & Info 1 & Info 2 & Info 3 & & \\
\hline $\begin{array}{c}\text { Implementation } \\
\text { outcomes }\end{array}$ & - & 4.0 & 3.0 & 3.0 & 2.7 & 3.2 & $\mathrm{~B}$ \\
\hline
\end{tabular}

Table22. Benefits of program activity implementation

\begin{tabular}{|c|c|c|c|c|c|c|c|}
\hline \multirow{3}{*}{ Aspects } & \multicolumn{5}{|c|}{ Assessment categories } & \multirow{3}{*}{ Score } & \multirow{3}{*}{ Grades } \\
\hline & \multirow[t]{2}{*}{ Observation } & \multirow{2}{*}{$\begin{array}{c}\text { Documentation } \\
\text { Study }\end{array}$} & \multicolumn{3}{|c|}{ Interview } & & \\
\hline & & & Info 1 & Info 2 & Info 3 & & \\
\hline $\begin{array}{c}\text { Implementation } \\
\text { benefit }\end{array}$ & - & 4.0 & 3.0 & 3.3 & 2.7 & 3.3 & $\mathrm{~B}$ \\
\hline
\end{tabular}

Table23. Impact of program activity implementation

\begin{tabular}{|c|c|c|c|c|c|c|c|}
\hline \multirow{2}{*}{ Aspects } & \multicolumn{5}{|c|}{ Assessment categories } & \multirow{2}{*}{ Score } & \multirow{2}{*}{ Grades } \\
\cline { 2 - 6 } & Observation & Documentation \\
\cline { 3 - 6 } & & Study & Info 1 & Info 2 & Info 3 & & \\
\hline $\begin{array}{c}\text { Implementation } \\
\text { impact }\end{array}$ & - & 4.0 & 2.6 & 2.6 & 3.0 & 3.1 & $\mathrm{~B}$ \\
\hline
\end{tabular}

Based on the evaluation results on the aspect of the product components get the average value of 3.2 with the predicate $\mathrm{B}$ and resulted in the decision that the program can be continued with the development. 


\section{CONCLUSION}

The results of the evaluation of the context component got results in a relatively good category and resulted in the decision that the program can proceed with the improvement. The results of the input component evaluation get results in both categories and result in the decision that the program can continue with the development. The results of the assessment of the process components get results in the right category and lead to the decision that the program can proceed with the development. The results of the evaluation of product components get results in good category and lead to the decision that the program can continue with the development.

\section{REFERENCES}

[1] Chen, Huey Tsyh, Practical Program Evaluation: Assessing and improving Planning, IMPLEMENTATION, AND EFFECTIVENESS. THOUSAND OAKS: SAGE PUBLICATION, 2005.

[2] Denzin, Norman K and Yvonna S Lincoln, Handbook of Qualitative Research. London: Sage Publication, Inc, International Educational and Professional Publisher, 2000.

[3] Dikmenjur, Pelaksanaan Prakerin. Jakarta: Direktorat Pembinaan SMK Depdiknas, 2008.

[4] Langbein, Laura \&Claire L. Felbinger, Public Program Evaluation: a Statistical Guide. New York: M.E. Sharpe, Inc, 2006.

[5] Mc David, James C., Laura R.L. Hawthom, Key Concepts and Issues in Program Evaluation and Performance Measurement, Chapter 2.London: Sage Publications, 2005.

[6] Perkins, David V, Dennis L Born, Joshua A. Raines \& Steven W. Galka, Program Evaluation From an Ecological Perspective: Supported Employment Services for Persons with serious Psychiatric Disabilities. Psychiatric Rehabilitation Journal, Vol. 28. No. 3, Winter, 2005.

[7] Rallis, Sharon F. \& Kathleen A. Bolland, What is Program Evaluation? Generating Knowledge for Improvement. Archival Science, Vol. 4, Spiring, 2005.

[8] Wholey, Joseph S dkk, Handbook of Practical Program Evaluation. CA: John Wiley \& Sons, Inc, 2010.

Citation: M. Sidik, et al "Evaluation of Industrial Work Practice Program Competence of Motorcycle Engineering Expertise Based on CIPP Model" International Journal of Managerial Studies and Research (IJMSR) vol 5, no. 9, 2017, pp. 30-36. doi:http://dx. doi.org/10.20431/2349-0381.0509006.

Copyright: (C) 2017 Authors. This is an open-access article distributed under the terms of the Creative Commons Attribution License, which permits unrestricted use, distribution, and reproduction in any medium, provided the original author and source are credited. 